\title{
Changing conceptions of historical thinking in History education: an Australian case study
}

\begin{abstract}
Many nations have experienced conflict over the content of their History curriculum, and debates over the relative importance of skills (historical thinking) versus content (historical knowledge). Australia is no exception. This paper seeks to contribute to discussions over the importance of historical thinking in History education by exploring the changing conceptions of historical thinking in the History curricula of New South Wales (NSW) (Australia's most populous state; which evolved from the earliest British colony; has an uninterrupted tradition of History teaching in high schools; and a rather unique post-compulsory extension course). Recently, History has become a mandatory subject in all Australian schools from the foundation year through to the last year of compulsory schooling [F-10], for the first time since the federation of the Australian states (1901), when curriculum was constitutionally determined to be a State responsibility. This paper charts the changing forms and relative importance of historical thinking as an explicit outcome of History education in NSW History curricula, from its emergence in the 1970 s elective History curriculum to current explication in the NSW syllabi for the mandatory Australian 'national' Curriculum. It also explores the nature and significance of the post-compulsory 'senior' History extension course in NSW, an option for History students in the final non-compulsory year of schooling. This extension course boldly incorporates the study of historiography, requiring students to apply their meta-historical insights in an original historiographic investigation, anchoring complex historical theory in an experience of being an historian. We argue that the move to incorporate historiography into the curriculum expands the notion of what constitutes historical thinking in History education. Thus, we conclude by reflecting on what these different ways of conceptualising historical thinking mean for the social and educational function of history, and what implications they suggest for History education.
\end{abstract}

Keywords: History Teaching; Historical Thinking; Australian.

To cite this article:

PARKES, Robert J.; DONNELLY, Debra. Changing conceptions of historical thinking in History education: an Australian case study. Revista Tempo e Argumento, Florianópolis, v. 6, n.11, p. 113136, jan./abr. 2014.

DOI: $10.5965 / 2175180306112014113$

http://dx.doi.org/10.5965/2175180306112014113 


\title{
Concepções em mudança do pensamento histórico no ensino da história: um estudo de caso australiano
}

\begin{abstract}
Resumo
Muitos países vivenciaram conflitos em torno do conteúdo do seu currículo de história e tiveram debates sobre a importância relativa de habilidades (pensamento histórico) versus conteúdo (conhecimento histórico). A Austrália não é uma exceção. Este artigo busca contribuir para as discussões sobre a importância do pensamento histórico no ensino da História explorando as concepções em mudança de pensamento histórico nos currículos de história de New South Wales (NSW) (o mais populoso estado da Austrália, que evoluiu de uma antiga colônia britânica e tem uma ininterrupta tradição de ensino de história no ensino médio, e um curso adicional ao ensino obrigatório, que é único no país). Recentemente, a história se tornou um tema obrigatório em todas as escolas australianas, desde o primeiro fundamental até o último ano da escola obrigatória (F-10), pela primeira vez desde a federalização dos estados australianos (1901), quando se determinava constitucionalmente que o currículo era uma responsabilidade do Estado. Este artigo mapeia as formas cambiantes e a importância relativa do pensamento histórico como um resultado explícito do ensino de história nos currículos de história de NSW, desde o seu surgimento no currículo de história eletivo da década de 1970 até a explicitação nas ementas de NSW para o Currículo "nacional" obrigatório australiano. Ele também explora a natureza e o significado do curso adicional "sênior" de história posterior à escola obrigatória de NSW, uma opção para os alunos de história no ano final não obrigatório de escolarização. Este curso adicional incorpora em grande medida o estudo da historiografia, exigindo dos alunos que apliquem suas intuições meta-históricas numa investigação historiográfica original, ancorando teoria histórica complexa numa experiência de ser historiador. Defendemos que esta atitude de incorporar a historiografia no currículo expande a noção do que constitui o pensamento histórico no ensino de história. Assim, concluímos com a reflexão sobre o que esses diferentes modos de conceituar o pensamento histórico significam para a função social e educacional da história, e quais implicações eles sugerem para o ensino da história.
\end{abstract}

Palavras-chave: Ensino da História; Pensamento Histórico; Austrália. 


\section{Introduction}

Many post-conflict, post-colonial, and settler nations have experienced heated 'history wars' over representations of the national past, leading to increasing political interest in History education (TAYLOR; GUYVER, 2011). In Australia, a decade of cultural conflict over the national narrative (see CLARK, 2004), led to the bi-partisan political support for a 'national' History curriculum (a significant development in the Federated Commonwealth of Australia, given curriculum is constitutionally a State responsibility, which has led to the failure of all previous attempts to form a national curriculum). With the advent of this new Australian 'national' curriculum (2013), History has become a mandatory area of study in every Australian state, from the first through to the final year of compulsory schooling.

As is commonplace in the curriculum history of many nations, History education has also frequently been a battleground for debates over the relative importance of skills (historical thinking) versus content (historical knowledge) (for an insightful exploration of this problem in the United Kingdom, see COUNSELL, 2000). Australia is no exception. This paper seeks to contribute to discussion over the importance of historical thinking in History education by exploring the changing conceptions of historical thinking in the History curricula of New South Wales (the most populous state, which evolved from the earliest British colony). New South Wales (NSW) has been selected as a case study for a number of reasons, not least its long uninterrupted tradition of History teaching in high schools, and more importantly, its rather unique post-compulsory History extension course.

The paper has three specific aims. Firstly, it documents the changing forms and relative importance of historical thinking as an explicit outcome of History education in NSW History curricula, from its emergence in the 1970s, and enhancement in the $1980 \mathrm{~s}$ elective History curriculum (influenced strongly by the work of the British Schools Council) to current explication in the NSW syllabus for the mandatory Australian 'national' Curriculum. Secondly, it explores the emergence and significance of the post-compulsory 'senior' History extension course in NSW, an option for History students (those studying Modern or Ancient History) in the final non-compulsory year of schooling. This extension 

investigation, anchoring complex meta-historical theory in an experience of being an historian. We argue that the move to incorporate historiography into the curriculum expands the notion of what constitutes historical thinking in History education, and thus our final aim is to reflect on what these different ways of conceptualising historical thinking mean for the social and educational function of history; and what the implications of such conceptualisations are for History education.

\section{Historical Thinking, Historical Understanding, and Historical Literacy}

Recent debates concerning the teaching of history in Australian schools have echoed international controversies that see a perceived lack of historical knowledge and engagement among young people as an indictment of both the curriculum and teaching practice. However, rather than a response to an educational failing, these debates are arguably a symptom of a paradigm shift in educational thought, and in History education in particular, that amounts to a delay in the broader community understanding of constructivist models of student learning. Under the influence of educational, cultural, and social development theories that reject learning as knowledge reception, "historical thinking" emerged as a term used by History educators to reject History education as simply a function of memorization and regurgitation. The decade-and-a-half old agreement in the educational literature is that historical thinking demands the development of heuristic and epistemological skills and concepts (WINEBURG, 2001; LEE, 2005), and so necessitates the production of History teachers with deep understanding of both their discipline and subject-specific pedagogy (VANSLEDRIGHT, 1996; WILSON and WINEBURG, 1998), a point we will return to later in this paper. However, any attempt at providing a definition of historical thinking presents an immediate difficulty, because there is no "standard" or assured meaning of the term itself.

Scholarship in the field of History education uses several terms that are, arguably, 
Unnatural Acts: Charting the Future of Teaching the Past; and Peter Seixas (2006), who developed an elaborated model for "historical thinking" in Benchmarks of Historical Thinking: A Framework for Assessment in Canada, which represented a shift from his earlier writings, in which "historical understanding" was used for much the same ideas (see, for example, Seixas, 1993a; 1993b). Wilson and Wineburg (1998) suggest four indicators of "depth" in history: (1) understanding the multiple facets of an historical concept or event; (2) knowing the details of these; (3) understanding the qualified incomplete nature of historical knowledge; and (4) being able to integrate these understandings into broader causal and thematic links. Wineburg (2001) also noted that the historians in his study explored a document's subtext by considering it both as a rhetorical artefact and as human instrument, using strategies of sourcing, corroboration and contextualisation. As an alternative to the notion of "historical thinking", educationalists also use the terms "Historical literacy" (TAYLOR and YOUNG, 2003; LEE, 2005; VIRTA, 2007) and "historical reasoning" (LEINHARDT; BECK; STAINTON 1994; VAN BOXTEL and VAN DRIE, 2004). Each of these terms underscores the importance given to the act of scrutinizing below the surface narrative (or interpretation) that is encountered, and involves what Lee and Ashby (2000) call second-order concepts or ideas. According to Lee and Ashby (2000, p. 199) "It is these ideas that provide our understanding of history as a discipline or form of knowledge". Historical thinking is thus a catholic term that embraces a range of approaches and modes of "doing history". We take it, in this paper, to be co-existent with "historical understanding", and that it encompasses both acts of "historical reasoning" and engagement in "historical literacy".

Over the last few decades History educators and researchers have endeavoured to clarify the components of historical thinking. Much of the initial research was conducted in the United Kingdom in association with the Schools History Project in the 1980 s. Shemilt's(1980) evaluation of this project is a seminal work on historical thinking and history education. It set out an approach that emphasized evidence as the building blocks 

influential Canadian scholar, Peter Seixas.

Seixas (2006) defines historical thinking as organizing collective experiences of the past, such that they form a meaningful way to think about the present. He suggests that there are three elements to students' historical understanding. The first is the ability to assign importance to historical information and to establish criteria by which to judge the significance of the various and often competing narratives of the past. The second element is the epistemological approach by which historical interpretations are revised through the inclusion of new evidence or opinion. This element involves the skills of source analysis, the integration of secondary opinion, and the application of frameworks by which to judge the reliability of the cacophony of voices that speak of the past to the present. The third element incorporates agency, empathy and moral judgement. Historical agency is the notion that individual choices, and the actions of individuals or groups, impact on the historical narrative and have intended and unintended consequences. Empathy is the ability to see beyond one's own time, culture and value system to appreciate agency in the past. It is the skill of understanding that allows the past a limited entry into the world of the present via historical imagination. Making moral judgements based on hindsight is inevitable when constructing meaning from historical narrative, not to apportion blame but make sense of the action and inaction of historical individuals or groups. Historical inquiry is a complex process involving analysing and interrogating individual sources of evidence; synthesizing their meaning and interrelationships; while simultaneously constructing new knowledge and integrating this new knowledge into existing narratives. To inquire historically is to engage in purposeful and reflective mental activities that focus on the strategic exploration of multiple perspectives through evaluation of reliability and perspective and the generation of interpretations and understandings (BARTON, 2004; WINEBURG, 2001).Together these complex intellectual activities constitute the skill of historical thinking. Having gained some sense of the complex activity of historical thinking, we now want to turn to the 


\section{The movement towards historical thinking in the $1970 \mathrm{~s}$}

An introductory 'Social Studies' curriculum in Form I (Year 7), followed by the possibility of an elective study of History in Forms II, III, and IV (Years 8-10) had been the pattern of study in NSW schools since the adoption of the "Wyndham Scheme" - a system of comprehensive secondary schooling first implemented in 1962 (JOHNSTON, 1982). The Wyndham reforms aimed to raise academic standards in part via the introduction of an external examination at the end of Form IV (a system that continued until recently); and each subject was offered at ordinary, credit, and advanced levels (BARCAN, 1980).

Throughout the 1960s, instruction in History had been guided by a "prescriptive, chronological syllabus ... programmed in fortnightly slabs of content" (JOHNSTON, 1982) that remained relatively unchanged until 1972 (CLARK, 2003). According to Anna Clark (2003, p. 173), the "critical approaches to Australian history" that were emerging from the academy during the 1960 s and 1970s, which were beginning to question "established interpretations of settlement and progress", inevitably had an impact on the history that was taught in schools. This impact had initially taken the form of an increasing focus on the construction of a "non-prescriptive" student-enquiry focused syllabus in 1972 "which maximised the freedom of teachers and pupils to choose content and methodology to suit their interests, ability levels and school circumstances" (JOHNSTON, 1982). However, it is worth noting that Australian history itself remained an area of study for the elective years.

In the 1971 syllabus there was a significant shift towards historical thinking skills with an emphasis on teaching "critical appraisal" and "interpretation" and giving students "an awareness of the some of the problems and techniques of the historian" (Secondary Schools Board, 1971, p. 3). For the first time students were positioned as active participants in making history, drawing upon skills such as "using and assessing 

people in other times and places" (Secondary Schools Board, 1971, p. 3). It included the concepts of "change and continuity" and emphasised the significance of history to the individual when it stated that, "the student should develop a sense of history as a continuing process in which he has a place" (Secondary Schools Board, 1971, p. 4). A discussion paper released in 1975 encapsulated the mood of the time, stating that "History is a natural study for the young, they are curious about the past... To deny History to the young is to deprive them of their cultural meaning, to make them social amnesiacs" (as cited in JOHNSTON, 1982, p. 72). In NSW, the 1972 syllabus revived the flagging fortunes of school History and firmly established it as a discrete subject, rather than part of a social science amalgam. It began the move towards historical thinking with its concepts of interpretation, appraisal, and empathy, and evoked a strong sense of purpose for school history as a subject that helped the young find their place in the world.

\section{The British influence in the 1980 s}

A new syllabus released in 1980 intensified the focus on the development of students' historical understanding in NSW (JOHNSTON, 1982). A wide range of topics were available for selection. They included the study of "Primitive Man" [sic] through the Renaissance, Britain under the Tudors; various aspects of the British Empire and European Imperialism generally; and Political Changes in Europe. There was a shift in Year 9 to Colonial Australian History, with some emphasis on local heritage, culminating with a broad-based view of Australian Twentieth Century history in a world context. This syllabus was noteworthy for its move away from the conception of history in "narrow subject matter terms" and the shift to "systematic attention being given to reasoning processes and skills, as well as values and attitudes" (FITZGERALD, 1981, p. 73). Teachers were given the freedom to create an environment in which students were to be 
School Council "History 13-16" Project. This is not surprising, as a British School Council team visited Australia during this period to disseminate their findings and approach, and ran a series of popular in-service workshops in NSW (JOHNSTON, 1982). The 1980 syllabus accords with the Projects' view that History "involves the search for evidence and clues about people in the past" and "involves asking questions." (Secondary Schools Board, 1980, p. 2). A major departure from previous syllabi, again following the British lead, was the prominence given to what was called "historical perspective." This notion encompassed the development in students of "a sense of time, a sense of cause effect relationships, and an understanding of the interactions of past and present" (Secondary Schools Board, 1980, p. 10). Most importantly, this notion culminated in the consideration of historical significance, "an understanding that History is a dynamic relationship of people, place and time in which some events can be judged to be more significant than others" (Secondary Schools Board, 1980, p. 10). Empathy was viewed as an essential partner to the development of historical perspective and central to the teaching and learning of History, providing an "ability to feel with, and learn from, the people of the past by imaginatively entering their world" (Secondary Schools Board, 1980, p. 11). With the 1980 Syllabus the understandings of historical thinking were prescribed for explicit teaching, learning, and assessment, and the students were encouraged to adopt the methodology and manifest the sensibilities of the historian, or what we might describe as a "disciplinary gaze" (seeing with the eyes of an historian). Thus, the 1980s registered a significant advance towards how we would think about historical thinking for the next three decades.

\section{The radical and reactionary $1990 \mathrm{~s}$}

The decade of the 1990s saw the beginnings of an increasing bureaucratization of curriculum, beginning with the emergence of a new statutory curriculum authority in 
and for those History educators attentive to curriculum change, as that moment in which Australian history was moved from its place of quarantine as an elective area of study, into a mandatory component of the NSW Years 7-10 History curriculum. There was certainly a degree of trepidation shown by teachers at this move to make Australian history compulsory, given that most students, and the majority of teachers themselves, appear - to this day - to find the topic of Australian history rather "boring" (CLARK, 2008). However, even if teachers themselves found little interest in Australian history, this was not the case for politicians and the conservative media for reasons that will become clear below.

Appearing in the wake of significant shifts and growing scholarship in Aboriginal historiography that gained public attention at the time of the Bicentennial, and Feminist histories that had been circulating since the sixties, the 1992 Syllabus was the first History syllabus in NSW to incorporate social histories about, and from the perspective of women and Australia's Indigenous peoples (PARKES, 2011). These new "perspectives" on the nation occurred largely under the influence of what has become known as the "New History" (OSBORNE; MANDLE, 1982). The "new histories" that came to the fore in the academy of the late 1970 and early 1980 s as social histories that "emphasized the lives of ordinary people" over the study of elites (MACRAILD; TAYLOR, 2004, p.120), legitimised the place in the NSW History curriculum of "history from below" (SHARPE, 1991), and presented it as an increasingly appealing option over the master narratives of "famous men" and "pioneering settlement". While "historical perspective" has been recognized as an aspect of history education in earlier syllabi, and was synonymous with the adoption of a historian's disciplinary gaze, the 1990s presented a rather different notion of "perspectives" as a critical component of historical thinking. What was meant by "perspectives" in the 1990s was no longer the adoption of the dispassionate, but disciplinary controlled, position of the historian (as was suggested by the notion of "historical perspective" in the 1980s), but an empathetic positioning of oneself in the 
A shift in the language that had traditionally described British colonisation as "settlement" to an unprecedented acknowledgment of the Aboriginal perspective on colonisation as "invasion", generated a great deal of angst among the conservative intelligentsia in NSW (MACINTYRE, 2004), Queensland (LAND, 1994), and Victoria (GRIMSHAW, 1996), where similar curricular changes had occurred. Described as "radical" by later commentators (THOMPSON, 1999; PARKES, 2007), this emphasis on the perspectives of historically marginalized groups within society, set History education on a collision course with conservative historians and politicians, making it a significant site of struggle in a series of heated and highly public "history wars" (MACINTYRE; CLARK, 2003). At the core of the "history wars" was a concern that the historical consciousness of the nation's youth was being hijacked by left-wing radicals intent on installing a "black armband" or mournful view of the nation's past (BLAINEY, 1993), undesirably influenced by "political correctness" (DONNELLY, 1997), cultural studies, literary theory, and postmodernism (WINDSCHUTTLE, 1996).

In many ways the struggles over history that occurred in NSW after the release of the 1992 syllabus, have been emblematic of conflicts over History education across the English-speaking world (ALDRICH, 1991; NASH; CRABTREE; DUNN, 1998; PHILLIPS, 1998; RICHARDSON, 2002), and in various post-conflict societies (AL-HAJ, 2005; AHONEN, 2012); and arguably reflected a global phenomenon (TAYLOR;GUYVER, 2011). What is perceived to be at stake in these "history wars" is the future of the nation (HALSE; HARRIS, 2004), because as Bennett (1995, p.162) has argued "the shape of the thinkable future depends on how the past is portrayed and on how its relations to the present are depicted". When a conservative federal government was elected in 1996, Blainey's rhetoric of "the balance sheet" and "black armband history" entered into the national lexicon, and NSW responded by developing what can only be described as a reactionary History syllabus, dumping the radical 1992 document in favour of a much more constrained, conservative, and content-driven syllabus in 1998 (see: Board of Studies Nsw, 1998). This highly 


\section{Historical thinking in the new millennium}

Although the new millennium began with an increased public awareness of the "history wars" (MACINTYRE; CLARK, 2003), the NSW History curriculum had settled the question of the relative importance of historical content and historical thinking, reemphasising the place of historical thinking in the curriculum, and enshrining it in new ways. It did this by making both content and skills explicit in the syllabus through a series of "learn about" (historical knowledge) and "learn to [do]" (historical skills) outcomes. Further, it required study - either as a discrete unit or integrated throughout other units of what it called "Investigating History", a topic that "introduces the nature of history and the methods used by historians to investigate the past" (Board of Studies Nsw, 2003, p. 16). It defined a set of six historical skills that were to be integrated into each topic of study, including: (1) comprehension; (2) analysis and use of sources; (3) perspectives and interpretations; (4) empathetic understanding; (5) research; and (6) communication (Board of Studies Nsw, 2003, p. 22). Finally, it articulated for each topic the historical skills that were to be integrated, and it described this section of each topic as "Working Historically". This was, arguably, the most explicit and detailed formulation of historical thinking skills that had been seen in a NSW syllabus.

When the conservative Prime Minister, John Winston Howard (2006), called for a "root and branch renewal" of Australian history, and instigated the move towards a national curriculum with his "National History Summit” in 2006, he was not only seeking a national narrative to unify the nation in the age of global terrorism (HOWARD, 2006), but also lamenting the fact that history had been relegated to an elective study in the postcompulsory years of schooling in most states and territories, and submerged within what he perceived as a politically "left-wing" integrated social studies curriculum. The National History Summit was to begin a move towards a national History curriculum, and papers that examined the teaching and learning of history in Australian schools (TAYLOR; 
received a favourable review in comparison with changes occurring to History curriculum in Britain (GUYVER, 2009), though the return of the Liberal conservative party to power in 2013 has brought with it the looming threat of a re-writing of the Australian curriculum even before it is fully implemented (CROWE, 2014).

Despite its uncertain long-term fate, the national curriculum in History has been slowly rolling out across the states, with implementation to begin in NSW in 2014. As its stands, the national curriculum is based on a survey-depth approach to the study of the past. $10 \%$ of the teaching time must be spent on an overview, however this may take the form of a discrete focus or be integrated with other studies (echoing the "Investigating History" component of the 2003 syllabus). The curriculum is divided into a series of depth studies, which include the ancient, Mediterranean, Asian, Western and Islamic, and AsiaPacific worlds, colonial contact history, and a range of topics in Australian history (including a mandatory study of Australia in WWI and WWII; and Aboriginal history from 1945 cast as a study of changing "Rights and Freedoms"). There is an important emphasis on Asia in the topic selection, and a noticeable World History perspective (the legacy of the narrative push described earlier, but also situated in the "World History" approach that appears to be becoming popular internationally).

Australia is now grappling with the implementation phase of a National History Curriculum that aims to bring a collective approach to the diverse state-run education systems. Historical skills and understanding feature strongly in the new national History syllabus are embedded in the objectives and outcomes. At the national level, the curriculum places emphasis on "historical knowledge and understanding" expressed as the key concepts of: evidence, continuity and change, cause and effect, significance, perspectives, empathy and contestability (translated as "history concepts" in the NSW syllabus). It places an equal emphasis on "historical skills" described as: chronology, terms and concepts; historical questions and research; analysis and use of sources; perspectives and interpretations; explanation and communication. Interestingly, in its 
of the elements of historical thinking outlined in the 2003 NSW History Syllabus, or at times a subtle reversion to the way they were expressed in this earlier document.

Certainly, it is rather ahistorical, but commonplace, to assume that the past was less "developed" than the present. When we look at the rather recent emergence of research into historical thinking, it is easy to assume that historical thinking must have been late to the curriculum. However, our investigation into the emergence and evolution of historical thinking in NSW History curriculum challenges this assumption. In fact, examining the curriculum documents of the 1970s through to the present shows a long tradition of focus upon the importance of developing historical thinking skills. With each instantiation of the curriculum, we can see a growing sophistication in the articulation of historical thinking. However, the compulsory curriculum is not the complete story in NSW, and we now want to switch focus to the unique History Extension course offered to excellent history students in their final non-compulsory year of schooling. We believe this "extension" curriculum offers a radically different approach to historical thinking that goes beyond the development of a disciplinary gaze, into the formation of meta-historical understanding.

\section{Historical Thinking, Historiography \& Extension History}

The senior History Extension course represents what became an exciting new move in NSW History curriculum. Emerging as part of the "New Higher School Certificate" in 2000, Extension History (as it is known locally), is an advanced course of study for talented or high achieving students completing either Ancient or Modern History (in their final year of post-compulsory schooling; what might have once been called the university matriculation pathway in NSW schools). Extension History focuses upon the work of historians over time; the role of historians in society; and the uses of the past. This course offers students the opportunity to research a topic of their own 

changed over time" (Board of Studies Nsw, 2000, p.6), this course of study places significant emphasis on the key debates that have occurred over the nature of historical knowledge, and thus introduces students to the various schools of historiography. Unlike the content-focused mandatory history curriculum, and in much of the writings of historians themselves, historical methodology is not assumed to be uniform, or always and everywhere the same. On the contrary, this Extension History course recognizes that different approaches to doing history have led to very different interpretations of the same past. In essence, it is a move from studying history, to engaging in serious metahistorical inquiry supported by careful scrutiny of the various historiographic traditions within which histories are produced, disseminated, and debated.

The Extension History program inducts students into what Parkes (2011) has termed the "historiographic gaze". This gaze involves extending the perceptual field of the historian so that nothing escapes it, not even themselves; thus revealing the historical specificity of all forms of historical knowledge and practice. It results in a recognition that not only are the traces of the past "historical" in a convention sense, but, following Gadamer (1992), that our own consciousness as historians is itself constructed within the horizons and prejudices of the historiographic traditions we have been inducted into. The historiographic gaze takes historical thinking to its logical conclusions, allowing nothing to stand outside of history. If the study of historiography renders visible the genealogy of a given historical representation by refurnishing it with a set of temporal moorings, the historiographic gaze compels us to acknowledge the contingent historical horizons within which all interpretation is produced. The study of history is transformed through this process, foregrounding the historicity and rhetorical construction of all interpretations of the past. Invoking the contingency of historical representation invites us to apprehend it as open to change, and never the final word. Historiography as a meta-theoretical discourse, reveals history to be a 'system of reasoning' that extends the gaze of the historian to everything, even themselves. The historiographic gaze is thus a disruptive 
Extension History presents to students what is arguably a reconceptualization of history. Its resistance to a taken for granted historical method, aligns well with the approach to history education argued for by Avner Segall (2006, p. 138) when he asserts that, "a critical perspective poses the following: according to what conventional and methodological practices, whose discourse, whose standards, whose past?" These questions invite an engagement with historiography and its competing traditions, each with their own conventions, methodologies, discourses, standards, and representations of the past. As Yilmaz (2007) argues, in order to understand histories we must have a clear sense of the historiographic traditions from which they emerge. Faced with competing accounts of a single event, students learning within a historiographic approach to teaching history can be tasked to explore not only alternative perspectives, but develop an understanding of how each of these perspectives has its own history, and is derived from the application of different principles, standards, and methodological approaches. Again, as Segall (2006, p.139) clearly states:

Questions of this sort help make visible and problematic the presuppositions of discourses, values, and methodologies that legitimate and enforce particular versions and visions as to what the past is and what knowing and acting upon it entail.

In taking on a historiographic approach to teaching History, two things become evident. Firstly, we need to understand that historical interpretations are constructed within particular historiographic traditions (such as Feminism, Marxism, Social History, Intellectual History, Cultural History, etc.), and hence are marked by the biases of those methodological traditions. Understanding the historiographic frame within which an historical narrative has been constructed is the first step towards understanding the historian's value-laden assumptions; disposition towards particular forms of interpretation; and concern with different forms of evidence. The second thing that emerges is that we come to understand how our own reading and interpretation of primary and secondary sources are prejudiced by the methodological biases of the historiographic traditions we have been initiated into (PARKES, 2009). Interestingly, 
students who had completed Extension History in high school came to university more prepared to engage in discussions with their lecturers and peers about the nature of historical knowledge. As Hughes-Warrington et al. explain, this suggests that Extension History develops students' capability to engage in historical discourse, in a way that doesn't happen with other approaches to historical thinking.

\section{Conclusions}

In this paper we have explored the emergence and changing conceptions of "historical thinking" in the NSW History curriculum and argue that it is possible to see a continuing interest in, and evolution of, historical thinking in curricula from the 1970 s to the present. Further, we would argue that the National History Curriculum can be understood in some respects as a dissemination of this evolution across the nation. Historical thinking skills are vital for democratic citizenship; the ability to discuss and listen to differing perspectives; consider a range of opinions and values; and come to reasonable conclusions; and they operate as a path to the development of a sophisticated historical consciousness, which the well-informed can use as a tool to navigate, understand, and interpret the social world. History teachers are often called upon to lead their charges into explorations of controversial issues, examining topics such as racism, slavery, genocide, religious divisions, rebellion and revolution. These issues resonate in the contemporary world and link to problems that we still grapple with (such as human rights and freedoms), and with which every future citizen needs to have a considered and informed position (BARTON, 2004). To engender historical understanding in their students by building their capacity for historical thinking, is surely the object of any history teacher. However, this ambitious pedagogical mission can become blurred in the systemic prescriptions and requirements of contemporary 
However, unlike the professional development that occurred for the teaching generation of the 1980s, there appears to be little government support for in-servicing teachers in the new national curriculum, and professional development looks like being left to professional teacher associations. While this may not be a problem for NSW, this could present difficulties in states where a general social studies curriculum has been the default and enduring practice. Certainly, in those states, it has been more likely that preservice teachers will experience a generic social studies method course that reduces history to "inquiry learning" and a bland sense of "continuity and change", not always having the curriculum space to attend to some of the more subtle dimensions of historical thinking that occurs when history is taught as a discrete method.

In this paper, we have also explored NSW's Extension History course, a successful curricular experiment that introduces senior History students to a detailed study of the nature of history and the range of historiographic traditions informing its construction. We've argued that the Extension History course offers a reconceptualized vision of historical thinking skills, going beyond the "disciplinary gaze" into the realm of metahistorical understanding. When confronted with competing historical narratives, the graduate of the Extension History course can draw on their understanding of historiography to provide adjudicating frames of reference through which to read alternative historical accounts, exposing the methodological biases and inherent assumptions underpinning the rival interpretations of the past they encounter. When historical thinking operates at this meta-disciplinary level, a critical consciousness emerges that assists its possessor to navigate the complex terrain of socio-cultural life. However, adopting an historiographic approach to History education, such as the one that emerged in the NSW Extension History course means that it is necessary for History educators, and certainly History teacher educators, to address historiography in the education and development of History teachers. Knowledge of historiography and its impact on methodology and forms of representation become central to the endeavour of representing history in classrooms. Divorced from historiography, any encounter with the 


\section{References}

AHONEN, Sirkka. Coming to terms with a dark past: how post-conflict societies deal with history. New York: Peter Lang, 2012.

AL-HAJ, Majid. National ethos, multicultural education, and the new history textbooks in Israel. Curriculum Inquiry, v. 35, n. 1, p. 47-71, 2005.

ALDRICH, Richard. History in the national curriculum. London: Kogan Page, 1991.

APPLE, Michael W. The hidden curriculum and the nature of conflict. In: PINAR, William (Org.). Curriculum theorizing: the reconceptualists. Berkley, C.A. McCutchan Publishing Corporation, 1975. p. 95-119.

BARCAN, Alan. A history of Australian education. Melbourne: Oxford University Press, 1980.

BARTON, Keith C. Teaching history for the common good. Chicago: Lawrence Erlbaum, 2004.

BENNETT, Tony. The birth of the museum: history, theory, politics. London: Routledge, 1995.

BLAINEY, Geoffrey. Drawing up a balance sheet of our history. Quadrant, v. 37, n. 7-8, p. 10-15, 1993.

BOARD OF STUDIES NSW. History stages 4-5 syllabus. Sydney, NSW: 1998.

BOARD OF STUDIES NSW. HSC history extension syllabus. Sydney, NSW: 2000.

BOARD OF STUDIES NSW. History years 7-10 syllabus (mandatory and elective courses). Sydney, NSW: 2003.

CLARK, Anna. Teaching the nation: politics and pedagogy in Australian history. Melbourne, VIC: Melbourne University Press, 2004.

CLARK, Anna. What do they teach our children? In: MACINTYRE, S.; CLARK, A. (Org.). The history wars. Melbourne: Melbourne University Press, 2003. p. 171-190. 
CLARK, Anna. History's children: history wars in the classroom. Sydney: University of New South Wales Press, 2008.

COUNSELL, Christine. Historical knowledge and historical skills: A distracting dichotomy. In: ARTHUR, James; PHILLIPS, Robert (Org.). Issues in History teaching. London: Routledge, 2000. p. 52-71.

CROWE, David. Christopher Pyne tackles leftist 'bias' in classrooms. The Australian. Canberra: News Corp Australia. Midday 2014.

DONNELLY, Kevin. The black armband view of history. Agora, v. 32, n. 2, p. 15, 1997.

FITZGERALD, Janis. History and the core curriculum: a response to core curriculum for Australian schools. Teaching History, v. 15, n. 2, p. 69-85, 1981.

GADAMER, Hans-Georg. Truth and method. New York: Crossroad, 1992.

GRIMSHAW, Pat. History: Searching for identity. Annual State Conference of the Queensland History Teachers Association (QHTA), 1996, Brisbane.

GUYVER, Robert. The shape of the Australian history curriculum: a comparative perspective. Agora, v. 44, n. 4, p. 9-16, 2009.

HALSE, Christine; HARRIS, Catherine. National identity and social cohesion: the social use of history curriculum in the United Kingdom, the US and Australia. Annual Conference of the Australian Association for Research in Education (AARE), 2004, University of Melbourne, November 28 - December 2, 2004.

HARRIS, Catherine. History curriculum development in New South Wales: issues of control and its impact on teachers. Annual Conference of the Australian Association for Research in Education (AARE), 2004, University of Melbourne, VIC.

HENDERSON, Deborah J. What is education for? Situating history, cultural understandings and studies of society and environment against neo-conservative critiques of curriculum reform. Australian Journal of Education, v. 49, n. 3, p. 306-319, 2005.

HOWARD, John. Unity vital in battle against terrorism. The Sydney Morning Herald. Sydney: 11 p. 2006.

HUGHES-WARRINGTON, Marnie et al. Historical thinking in higher education: An ALTC discipline-based initiative. Australian Learning and Teaching Council. Sydney. 2009

JOHNSTON, Gary. An historical perspective of the 1980 syllabus in history for years 7-10. Teaching History, v. 15, n. 4, p. 65-81, 1982. 
LAND, Ray. Invasion and after: a case study in curriculum politics. Brisbane: Queensland Studies Centre, 1994.

LEE, Paul. Historical literacy: Theory and Research. International Journal of Historical Learning, Teaching and Research, v. 5, n. 1, 2005.

LEE, Paul; ASHBY, Rosalyn. Progression in historical understanding ages 7-14. In: STEARNS, Peter N.; SEIXAS, Peter; WINEBURG, Samuel(Org.). Knowing, teaching, and learning history: national and international perspectives. New York: New York University Press, 2000. p. 199-222.

LEINHARDT, Gaea; BECK, IsabelL.; STAINTON, Catherine. Teaching and learning in history. Hillsdale, NJ: Lawrence Erlbaum Associates, 1994.

MACINTYRE, Stuart. The history wars. Teaching History, v. 38, n. 2, p. 4-14, 2004.

MACINTYRE, Stuart; CLARK, Anna. The history wars. Melbourne: Melbourne University Press, 2003.

MACRAILD, Donald M.; TAYLOR, Avram. Social theory and social history. London: Palgrave Macmillan, 2004.

MELLEUISH, Gregory. The teaching of Australian history in Australian schools: a normative approach. The Australian History Summit, 2006, Canberra. August 17.

NASH, Gary B.; CRABTREE, Charlotte; DUNN, Ross E. History on trial: culture wars and the teaching of the past. New York: Alfred A, Knopf, 1998.

OSBORNE, Graeme; MANDLE, WilliamFrederick (Orgs.). New history: studying Australia today. Sydney: George Allen \&Unwined. 1982.

PARKES, Robert John. Reading History curriculum as postcolonial text: towards a curricular response to the history wars in Australia and beyond. Curriculum Inquiry, v. 37, n. 4, p. 383-400, 2007.

PARKES, Robert John. Teaching History as historiography: engaging narrative diversity in the curriculum. International Journal of Historical Learning, Teaching and Research, v. 8, n. 2, p. 118-132, 2009.

PARKES, Robert John. Interrupting history:rRethinking history curriculum after 'the end of history'. New York: Peter Lang, 2011.

PHILLIPS, Robert. History teaching, nationhood and the state: a study in educational politics. London: Cassell, 1998. 
RICHARDSON, George H. The death of the good Canadian: teachers, national identities, and the social studies curriculum. New York: Peter Lang, 2002.

SECONDARY SCHOOLS BOARD. History Syllabus: secondary Schools. Sydney, NSW: Secondary Schools Board 1971.

SECONDARY SCHOOLS BOARD. History in N.S.W. secondary Schools, Years 7-10. Sydney, NSW: Secondary Schools Board, 1980.

SEGALL, Avner. What's the purpose of teaching a discipline, anyway? In: SEGALL, Avner; HEILMAN, Elizabeth; CHERRYHOLMES, Cleo H (Org.). Social studies - the next generation: re-searching in the postmodern. New York: Peter Lang, 2006. p. 125-139.

SEIXAS, Peter. Historical understanding among adolescents in a multicultural setting. Curriculum Inquiry, v. 23, n. 3, p. 301-327, 1993 a.

SEIXAS, Peter. Popular film and young people's understanding of the history of Native American-White relations. The History Teacher, v. 26, n. 3, p. 351-370, 1993 b.

SEIXAS, Peter. Benchmarks of Historical Thinking: a framework for assessment in Canada. Centre for the study of historical consciousness, University of British Columbia.

Vancouver, CA. 2006

SHARPE, Jim. History from below. In: BURKE, Peter(Org.). New perspectives on historical writing. Cambridge, UK: Polity Press, 1991. p. 24-41.

SHEMILT, Denis. History 13-16: evaluation study. Edinburgh: Holmes McDougall, 1980.

TAYLOR, Tony. Howard's End: a narrative memoir of political contrivance, neoconservative ideology and the Australian history curriculum. Curriculum Journal, v. 20, n. 4, p. 317-329, 2009. ISSN 0958-5176.

TAYLOR, Tony; CLARK, Anna. An overview of the teaching and learning of Australian history in schools. The Australian History Summit, Canberra. Canberra 2006.

TAYLOR, Tony; GUYVER, Robert(Orgs.). History wars in the classroom: Global perspectives. London: Information Age Publishinged. 2011.

TAYLOR, T.; YOUNG, C. Making history: A guide for the teaching and learning of history in Australian schools. Carlton South, VIC: Curriculum Corporation, 2003.

THOMPSON, K. Civics and citizenship education in New South Wales and its implications for teaching history. 1999. thesis submitted in partial fullfilment of the requirements for the degree of Bachelor of Education (Honours) Faculty of Education, The University of Sydney 
VAN BOXTEL, C; VAN DRIE, J. Historical reasoning: a comparison of how experts and novices contextualise historical sources. International Journal of Historical Learning, Teaching and Research, v. 4, n. 2, 2004.

VANSLEDRIGHT, B. A. Closing the gap between school and disciplinary history? Historian as high school history teacher. In: BROPHY, J (Org.). Advances in Research on Teaching. Greenwich, Conn.: JAI Press, v.6, 1996. p. 257-289.

VIRTA, A. Historical literacy: Thinking, reading and understanding history. Journal of Research in Teacher Education, v. 14, n. 4, p. 11-25, 2007.

WILSON, S. M.; WINEBURG, S. Peering at history through different lenses: the role of disciplinary perspectives in teaching history. Teachers College Record, v. 89, n. 4, p. 525539, 1998.

WINDSCHUTTLE, K. The killing of history: How literary critics and social theorists are murdering our past. New York: The Free Press, 1996.

WINEBURG, S. Historical thinking and other unnatural acts. Canadian Historical Consciousness in an International Context: theoretical Frameworks conference, 2001, University of British Columbia, Vancouver, BC.

WINEBURG, S. Historical thinking and other unnatural acts: charting the future of teaching the past. Philadelphia: Temple University Press, 2001.

YILMAZ, K. Introducing the 'linguistic turn' to history education. International Education Journal, v. 8, n. 1, p. 270-278, 2007. 
Recebido em: 10/01/2014 Aprovado em: 10/03/2014

Universidade do Estado de Santa Catarina - UDESC Programa de Pós-Graduação em História - PPGH

Revista Tempo e Argumento Volume 06 - Número 11 - Ano 2014 tempoeargumento@gmail.com 